\title{
Molecular Model and Structural Stability Study of a Nafion lonomer-Based Membrane Electrode Assembly
}

DOI: $10.15255 /$ KUI.2016.017

KUI-30/2016

Original scientific paper

Received April 22, 2016 Accepted July 25, 2016

\author{
C. Feng a and P. F. He ${ }^{b^{*}}$ \\ ${ }^{a}$ College of Materials Science and Engineering, Key Laboratory for Advanced Civil \\ Engineering Materials (Ministry of Education), Tongji University, Shanghai 201804, \\ P. R. China \\ b School of Aerospace Engineering and Applied Mechanics, Tongji University, \\ Shanghai 200092, P. R. China
}

\begin{abstract}
A Abstract
One of the most important parts of a polymer electrolyte membrane fuel cell (PEMFC) is the membrane electrode assembly (MEA). However, the delamination between the membrane and electrode layers, induced by uneven distribution of internal stress and stress concentration due to the inconsistent water and thermal expansion properties, greatly reduces the PEMFC durability. Based on the data from the literature or use of commercial products, this work established the molecular model of membrane and electrode layers, and aimed to find the stable structure of MEA. Nafion ionomer and its composite with graphite-supported platinum were considered as a proton exchange membrane and catalyst electrode layer materials, respectively. Molecular dynamics simulations were employed to investigate the coefficients of thermal and water expansion of membrane and electrode layers. The structural stability of a three-layer MEA model (anode-membrane-cathode) was discussed by exerting various external pressures and calculating the binding energies between layers and between graphene and platinum. The results showed that very high pressures squeeze the internal molecules excessively, resulting in the platinum particles detaching from their support material, while lower pressure weakens the binding between layers.
\end{abstract}

\author{
\| Keywords \\ Molecular dynamics, membrane electrode assembly, coefficient of thermal expansion, \\ coefficient of moisture expansion, binding energy
}

\section{Introduction}

In recent years, environmental pollution has been the focus of much research, and practical applications of clean energy technologies have undergone rapid development, particularly the fabrication of proton exchange membrane fuel cells (PEMFCs). Although PEMFC products have been put into production, low durability still limits their full development. A three-layer membrane electrode assembly (MEA) without a gas diffusion layer, generally fabricated using the catalyst-coated membrane (CCM) technique, is the core part of a PEMFC, and its properties directly determine PEMFC durability. ${ }^{1}$ In a MEA system, the electron-, proton-, and water-transfer processes in the wet-heat cyclic loading easily cause internal mechanical damage. Although chemical interactions are a direct threat to PEMFC durability, the effects of internal mechanical damage cannot be ignored. ${ }^{2}$ Some workers have confirmed that the delamination of electrodes and the proton exchange membrane is the main cause of MEA failure. ${ }^{3-5}$ The facts that the electrode [also called a catalyst layer $(\mathrm{CL})$ ] and proton exchange membrane have different water and thermal expansion properties, and that the working processes of material bending, stretching, etc. in the MEA layers are not

\footnotetext{
${ }^{*}$ Corresponding author: Prof. Pengfei He
}

e-mail:ph232@tongji.edu.cn synchronized, causes an uneven distribution of internal stress and stress concentration, leading to electrode cracking and membrane splitting off from the electrode layers. ${ }^{6-8}$

With the complexity of preparation processes and the work environment, it is difficult to accurately measure MEA properties using conventional macroscopic techniques and methods. It is well known that to great extent microstructures determine the properties of macroscopic material. Therefore, microstructure analysis of the performance of membranes and CLs has become significant. Molecular dynamics (MD) simulation is currently a popular research method for analysing the physical properties of nanoscale materials. MD simulation has various potential functions to describe the interaction between atoms in different molecular systems, and has been used to successfully analyse the thermomechanical properties of polymer materials, ${ }^{9-10}$ including the microstructure comprising a hydrated perfluorosulphonic acid (PFSA) membrane $\mathrm{e}^{11-16}$ and a composite catalyst electrode layer. ${ }^{17-18}$

In this work, we selected Nafion as a membrane material, and a compound of Nafion and graphene-supported platinum (GN/Pt) as a CL material. The reasons for our choice are: (1) the Nafion membrane series produced by DuPont are the most effective proton exchange membranes; (2) graphene, due to its ability to cover a large surface area $\left(\approx 2600 \mathrm{~m}^{2} \mathrm{~g}^{-1}\right)$ and good electrical conductivity, is consid- 
ered an excellent catalyst and carrier of metal particles; ${ }^{19}$ and (3) GN/Pt is a promising catalyst for PEMFC electrodes. ${ }^{20-21}$ In addition, an ion polymer solution in a $\mathrm{CL}$ plays the role of a bonding and transmission medium, ${ }^{22}$ and generally has a similar chemical composition as membrane material. Thus, Nafion is also considered to play the role of a bond in CLs. The purpose of this work is to devise a method of designing a MEA molecular model with excellent structural stability.

\section{Model Establishment}

\subsection{Membrane model}

The chemical formula of the selected Nafion membrane is shown in Fig. 1(a); it has a similar molar mass (1143 $\left.\mathrm{g} \mathrm{mol}^{-1}\right)$ as repeating units of Nafion $117\left(\approx 1100 \mathrm{~g} \mathrm{~mol}^{-1}\right)$. Five monomers are included in a single chain, and 16 single chains form a Nafion oligomer. They were constructed in a tetragonal lattice, and then subjected to geometric optimization under an external pressure of $0.1 \mathrm{GPa}$. Fig. 1(b) shows the optimized structure with a density of $1.7 \mathrm{gcm}^{-3}$.

(a)

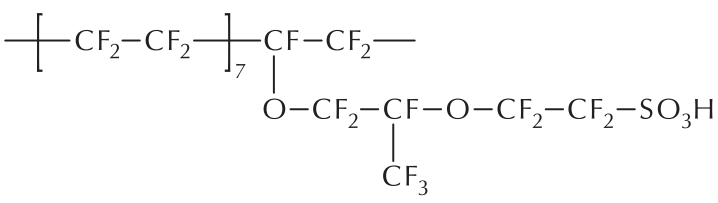

(b)

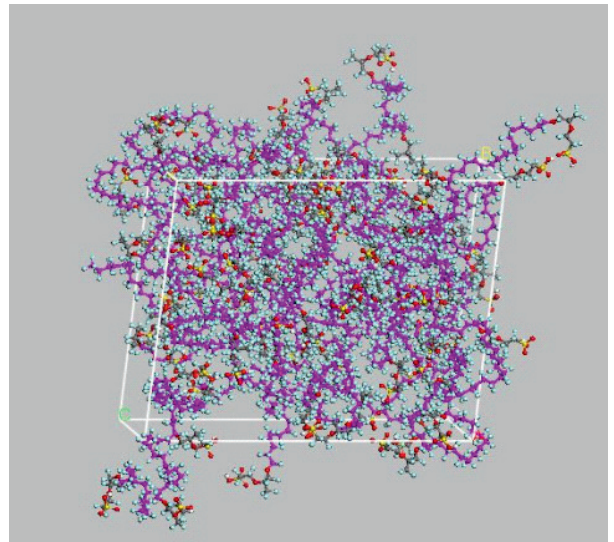

Fig. 1 - (a) Structural formula of Nafion monomer; (b) structure of Nafion oligomer, with cell parameters $a=42.4 \AA, b=42.6 \AA, c=50.3 \AA, \alpha=96.6^{\circ}$, $\beta=95.2^{\circ}, \gamma=94.1^{\circ}$

Slika 1 - (a) Strukturna formula monomera Nafiona; (b) struktura oligomera Nafiona, s parametrima jedinične ćelije $a=42,4 \AA, b=42,6 \AA, c=50,3 \AA, \alpha=96,6^{\circ}, \beta=95,2^{\circ}$, $\gamma=94,1^{\circ}$

In an aqueous environment, Nafion oligomer is completely ionized, i.e., the number of hydronium ions $\left(\mathrm{H}_{3} \mathrm{O}^{+}\right)$is equal to that of $-\mathrm{SO}_{3}{ }^{-}$; thus, the system remains electroneutral. The increase in water levels would increase proton conductivity, but at the same time reduce the mechanical properties. We considered four different humidity lev- els for Nafion molecular structures, and the corresponding hydration levels are $\lambda=0,4,9,13$ and 17 among $\lambda=\left(N_{\mathrm{H}_{2} \mathrm{O}}+\mathrm{N}_{\mathrm{H}_{3} \mathrm{O}^{+}}\right) / \mathrm{N}_{\mathrm{SO}_{3}}$, where $N$ is the number of particles. Hydration levels higher than 17 is considered as the relative humidity above $95 \%$.

\subsection{CL model}

Commercial catalysts have Pt particle diameters ranging from 1 to $3 \mathrm{~nm}$ and show good performance, e.g., Pt/carbon black (Hispec 3000, Johnson Matthey Co.). Two different diameters of Pt particles, 1.2 and $1.6 \mathrm{~nm}$, are considered in our model. Anode and cathode models are differentiated by layer thickness and Pt content. In experiments, catalysts in an anode generally show an excellent catalytic efficiency with a lower mass fraction of Pt than in a cathode. Thus, here we consider a Pt mass fraction of $\approx 20 \%$ in the anode $\mathrm{CL}$, and $\approx 30 \%$ in the cathode CL. Four-layer graphene is used for supporting the Pt cluster. The initial configurations of the anode and cathode layers are shown in Figs. 2(a) and 2(b), and their depths are, respectively, 34 and $42 \AA$ in the $z$ direction. It is also considered that in an aqueous environment, all of the sulphonic acids in a $\mathrm{CL}$ are completely ionized.

(a)

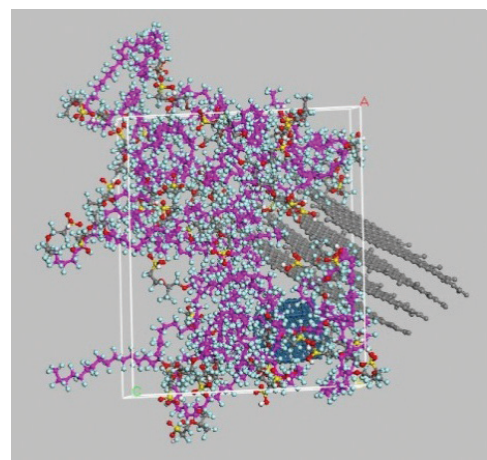

(b)

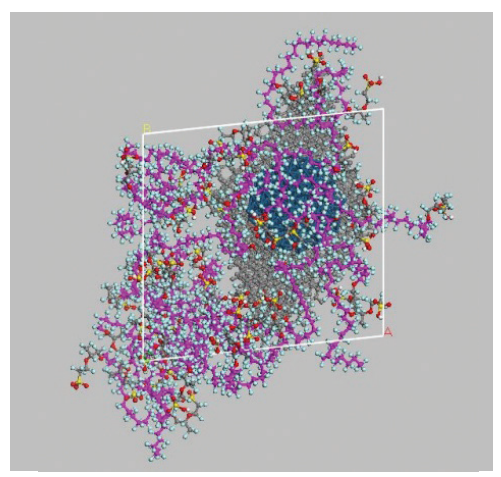

Fig. 2 -Molecular model of (a) anode $\mathrm{CL}$ with the cell parameters: $a=44.4 \AA, b=38.8 \AA, c=35.8 \AA, \alpha=93.2^{\circ}$, $\beta=92.9^{\circ}, \gamma=73.3^{\circ}$; and (b) cathode $\mathrm{CL}$ with the parameters: $a=40.9 \AA, b=39.6 \AA, c=42 \AA, \alpha=75.5^{\circ}$, $\beta=88.8^{\circ}, \gamma=83.9^{\circ}$

Slika 2 - Molekulski model (a) anode CL s parametrima jedinične ćelije: $a=44,4 \AA, b=38,8 \AA, c=35,8 \AA, \alpha=93,2^{\circ}$, $\beta=92,9^{\circ}, \gamma=73,3^{\circ} ; \mathrm{i}$ (b) katode $\mathrm{CL}$ s parametrima: $a=40,9 \AA, b=39,6 \AA, c=42 \AA, \alpha=75,5^{\circ}, \beta=88,8^{\circ}$, $\gamma=83,9^{\circ}$ 


\subsection{MEA model}

The CCM-MEA preparation is implemented by means of hot packaging of the proton exchange membrane and electrode layers to achieve close contact. In our initial MEA model, we construct a layer-by-layer structure along the $z$ direction (thickness direction) according to the equilibrium structures of the membrane and electrode layers after MD simulation, like a sandwich model, in which the membrane is in the middle, with the two sides being the anode and cathode layers.

\section{Simulation Methods}

\subsection{Computational details}

The MD simulations are carried out using Materials Studio commercial software. In Nafion systems, we use the Dreiding force field ${ }^{23}$ to describe the interaction between atoms. This force field has been commonly used in earlier MD simulations of proton exchange membranes. ${ }^{24-25}$ In the $\mathrm{CL}$ system, the universal force field (UFF ${ }^{26}$ is applied to describe the interaction of all atoms, including the interaction of $\mathrm{Pt}$ atoms, carbon atoms, and the atoms of the Nafion oligomers. The UFF has been successfully used in the systems containing all of the atoms in the models used in the present work. ${ }^{27-29}$ For the initial system constructed, we first conducted a geometric optimization, with ultrafine precision.

After geometric optimization, a 60 ps annealing simulation, with a time step of $1 \mathrm{fs}$ and using a constant pressure and temperature (NPT) ensemble, is performed in each system, where temperature and pressure are maintained, respectively, by a Nose thermostat and a Berendsen barostat, at a pressure of $0.1 \mathrm{GPa}$, an initial temperature of $300 \mathrm{~K}$, a middle cycle temperature of $500 \mathrm{~K}$, and cycle times of 30 . Then, for the last equilibrium structures with minimum potential energy, we continued 100 ps MD simulations at various temperatures, and recorded the last 20 ps of structures for collecting data such as the energy, density, and volume; we then averaged these values for further analysis.

Finally, we construct a three-layer MEA model according to the above equilibrium structures, and then geometrically optimize it. A quench MD simulation with a 200 ps simulation time and $1 \mathrm{fs}$ time step was performed in succession to globally determine the equilibrium structure with the lowest energy. The NPT ensemble with $298 \mathrm{~K}$ temperature was exploited. Then for each model, we analysed the equilibrium structures and calculated the binding energy between the layers, the GN and the Pt cluster.

\subsection{Coefficient of thermal expansion}

The coefficient of thermal expansion (CTE) can characterize the physical quality of a body, and here we mainly focus on the volume expansion. At a certain pressure, when a body's temperature increases by $1 \mathrm{~K}$, the CTE is expressed by the ratio of its volume change to its corresponding volume at $298 \mathrm{~K}\left(25^{\circ} \mathrm{C}\right)$, as a function of temperature,

$$
\gamma(T)=\frac{1}{V_{0}} \cdot \frac{\Delta V}{\Delta T}
$$

where $V_{0}$ denotes the volume of the system at $298 \mathrm{~K}, \Delta V$ the volume change, and $\Delta T$ the temperature change.

\subsection{Coefficient of moisture expansion}

Letting $M$ be the humidity (water content), $V_{0}$ the system volume at room temperature $(298 \mathrm{~K})$ in a dry state, the coefficient of moisture expansion (CME) can be expressed by

$$
\alpha=\frac{1}{V_{0}} \cdot \frac{\Delta V}{\Delta M}
$$

$\Delta M$ is humidity change.

\section{Results and Discussion}

We investigated the coefficients of thermal and moisture expansion according to the PEMFC working temperature (298-358 K) and humidity (hydration), respectively.

\subsection{Coefficient of thermal expansion}

The composition and the corresponding content of membrane and CLs are listed in Table 1. Five different temperatures were considered, i.e., 298, 313, 328, 343, and $358 \mathrm{~K}$, to study the relationship between the CTE and temperature, as shown in Fig. 3. It is seen that the CTE appears to change nonlinearly, and in the earlier period of temperature change, it is much higher, and then upon increasing temperature, the CTE of each layer will reach a similar value, $343 \mathrm{~K}\left(45^{\circ} \mathrm{C}\right)$, i.e., $\approx 2 \cdot 10^{-4} \mathrm{~K}^{-1}$. This value is similar to that of pure water. The CTE for a Nafion membrane gradually decreases with the temperature, while for anode and cathode CLs, the CTE decreases from 313 to $343 \mathrm{~K}$, then increases slightly. This inconsistent expansion process easily results in an uneven distribution of internal stress and stress concentration. This deference is mainly caused by the addition of $\mathrm{Pt}$ and $\mathrm{GN}$, which provides an increase trend in CTE-temperature curve at the range from 343 to $358 \mathrm{~K}$. Moreover, the CTE of cathode $\mathrm{CL}$ is much larger than that of anode CL. It demonstrates that the Pt content has also an important influence on CTE, the larger the Pt content, the smaller the CTE will be.

Table 1 - Composition of each layer of the MEA

Tablica 1 - Sastav slojeva MEA-e

\begin{tabular}{l|c|c|c}
\hline $\begin{array}{l}\text { Layer } \\
\text { Sloj }\end{array}$ & $w(\mathrm{GN}) / \%$ & $w(\mathrm{Pt}) / \%$ & $w($ Nafion $) / \%$ \\
\hline $\begin{array}{l}\text { anode layer } \\
\text { anodni sloj }\end{array}$ & 12.4 & 20.3 & 67.3 \\
$\begin{array}{l}\text { membrane } \\
\text { membrana }\end{array}$ & 0 & 0 & 0 \\
$\begin{array}{l}\text { cathode layer } \\
\text { katodni sloj }\end{array}$ & 15 & 29.2 & 55.8 \\
\hline
\end{tabular}




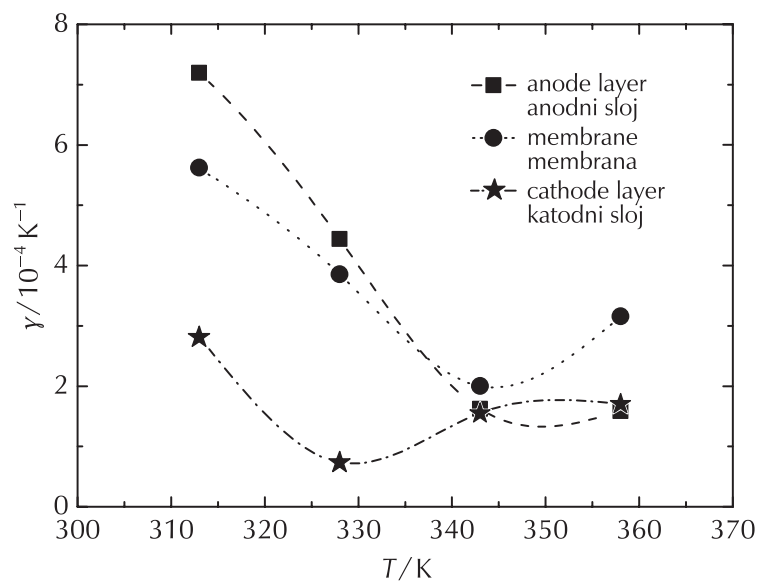

Fig. 3 - Relationship of CTE and temperature for membrane and $\mathrm{CL}$ systems

Slika 3 - Odnos CTE-a i temperature za membranu i elektrodne slojeve

\subsection{Coefficient of moisture expansion}

Various water contents were examined for each MEA layer, and the corresponding parameters - the number of particles and hydration level $(\lambda)$ - are listed in Table 2 . When the water content reaches $21 \%$ of mass in the hydrated membrane, there will exist a continuous water channel where protons can smoothly migrate from the anode to cathode layer using $\mathrm{SO}_{3}{ }^{-}$as a carrier. Compared to the membrane working environment and its performance, the mass fraction of water in CLs is much lower; In this work, we determined an upper limit of $17 \%$ for the anode $\mathrm{CL}$ and $10.2 \%$ for the cathode CL. Owing to the Pt cluster having a larger number of atoms (139) in the cathode layer, its binding force with $\mathrm{GN}$ will become weaker when the water content is higher under a pressure of $0.1 \mathrm{GPa}$, i.e., the increase in the number of water molecules and hydronium ions will greatly reduce the interaction between the Pt cluster and $\mathrm{GN}$. In our simulation, when the mass

Table 2 - Water content and number of particles in membrane and electrode layers

Tablica 2 - Vlažnost i broj čestica u mebrani i elektrodnim slojevima

\begin{tabular}{l|r|r|r|r|r}
\hline $\begin{array}{l}\text { Layer } \\
\text { Sloj }\end{array}$ & $N\left(\mathrm{H}_{3} \mathrm{O}^{+}\right)$ & $N\left(\mathrm{H}_{2} \mathrm{O}\right)$ & $N\left(\mathrm{SO}_{3}{ }^{-}\right)$ & $\lambda$ & $\mathrm{M} / \%$ \\
\hline \multirow{2}{*}{$\begin{array}{l}\text { anode } \\
\text { anoda }\end{array}$} & 45 & 0 & 45 & 1 & 2.3 \\
& 45 & 135 & 45 & 4 & 8.4 \\
\hline \multirow{2}{*}{$\begin{array}{l}\text { membrane } \\
\text { membrana }\end{array}$} & 85 & 360 & 45 & 9 & 17 \\
\hline \multirow{2}{*}{$\begin{array}{l}\text { cathode } \\
\text { katoda }\end{array}$} & 80 & 240 & 80 & 4 & 6 \\
& 45 & 1280 & 80 & 17 & 21 \\
\hline
\end{tabular}

fraction of water reaches $16 \%$ in the cathode layer, the $\mathrm{Pt}$ cluster totally detaches from the graphene.

According to Eq. (2), we can obtain the CME of each MEA layer under different levels of moisture, as shown in Fig. 4. It is observed that the CME of the membrane increases slowly with increasing temperature, while there is a decline in the $\mathrm{CL}$. As reported by He et al., ${ }^{30} \mathrm{Pt}$ nanoparticle had a stronger attraction to water molecules than sulfonic acid group and hydronium ion, thus the introduction of Pt nanoparticle can produce a large $\mathrm{CME}$, particularly in the initial stage of moisture. Furthermore, as Pt content increases, CME of CL system has also a significant growth. In addition, all three layers exhibit a rapid change in volume at the initial stage of moisture adsorption, which corresponds to a much larger CME value; then, with an increase in the number of water molecules, i.e., in the late stage of adsorption, although the volume still swells, the CME changes negligibly, reaching a constant value.

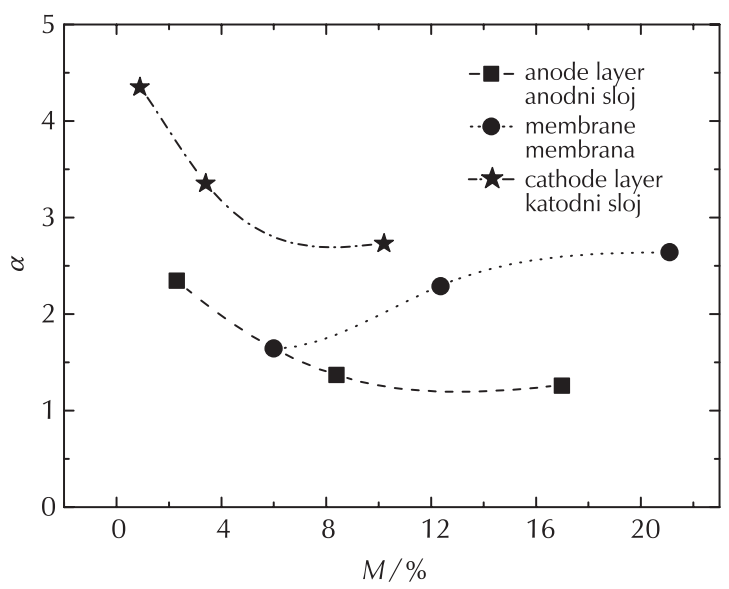

Fig. 4 - Relationship of CME and humidity for membrane and CL systems

Slika 4 - Odnos CME-a i vlažnosti za membranu i elektrodne slojeve

\subsection{Structural stability}

Five external pressures $(0.1,0.2,0.5,1$, and $2 \mathrm{GPa})$ were used to investigate the structural stability of MEA models according to binding-energy calculations. The equilibrium structure of a MEA with the lowest potential energy was chosen for further analysis, and the potential energies of each individual component were calculated, i.e., that of the membrane and anode layer, membrane and cathode layer, GN and Pt, membrane, anode layer, cathode layer, $\mathrm{GN}$, and Pt cluster. The binding energy between two systems is defined as the total energy of the compound system minus the energies of each system. Table 3 lists the potential energy of the MEA structure $\left(E_{\mathrm{MEA}}\right)$ and the binding energies between the membrane and anode layer $\left(E_{\mathrm{B} / \mathrm{M}-\mathrm{A}}\right)$, the membrane and cathode layer $\left(E_{\mathrm{B} / \mathrm{M}-\mathrm{C}}\right), \mathrm{GN}$ and Pt clusters in the anode $\left(E_{\mathrm{B} / \mathrm{GN}-\mathrm{P} / / \mathrm{A}}\right)$ and cathode layers $\left(E_{\mathrm{B} / \mathrm{GN} \text {-Pt/C}}\right)$ under various pressures. 
Table 3 - Potential energy of the MEA structure and the binding energies between layers, GN and Pt clusters under various pressures

Tablica 3 - Potencijalna energija strukture MEA-e i vezne energije između slojeva, grafena i platinskoih klastera pri različitim tlakovima

\begin{tabular}{|c|c|c|c|c|c|}
\hline$\frac{p}{\mathrm{GPa}}$ & $\frac{E_{\mathrm{MEA}}}{\mathrm{kcal} \mathrm{\textrm {mol } ^ { - 1 }}}$ & $\frac{E_{\mathrm{B} / \mathrm{M}-\mathrm{A}}}{\mathrm{kcal} \mathrm{\textrm {mol } ^ { - 1 }}}$ & $\frac{E_{\mathrm{B} / \mathrm{M}-\mathrm{C}}}{\mathrm{kcal} \mathrm{\textrm {mol } ^ { - 1 }}}$ & $\frac{E_{\mathrm{B} / \mathrm{GN} \text {-Pt/A }}}{\mathrm{kcal} \mathrm{mol} \mathrm{m}^{-1}}$ & $\frac{E_{\mathrm{B} / \mathrm{CN}-\mathrm{Pt} / \mathrm{C}}}{\mathrm{kcal} \mathrm{\textrm {mol } ^ { - 1 }}}$ \\
\hline 0.1 & 15 & -348.7 & -251 & -16.35 & -10.34 \\
\hline 0.2 & 149409.2 & -321.23 & -268.26 & -17.38 & -20.47 \\
\hline 0.5 & 153739.3 & -355.08 & -329.19 & -12.83 & -10.28 \\
\hline 1 & 154106.7 & -360.32 & -312.59 & -18.29 & -6.67 \\
\hline 2 & 151870.5 & -355.84 & -294.82 & -17.07 & -3.38 \\
\hline
\end{tabular}

It was observed that the energy of the MEA structure had the lowest value under a pressure of $0.2 \mathrm{GPa}$; thus it is an energetically stable structure [see Fig. 5(a)]. In addition, the results of the binding energies show that the larger the external pressure is, the larger the binding energy between layers will be; whereas, this conclusion is not valid for GN and the Pt cluster. When the pressure is $1 \mathrm{GPa}$, we find the lowest binding energy $\left(-6.67 \mathrm{kcal} \mathrm{mol}^{-1}\right)$ for $\mathrm{GN}$ and the Pt cluster in the cathode layer, and it can be seen from Fig. 5(b) that the Pt cluster almost detaches from graphene. Because GN and the Pt cluster interact quite weakly (van der Waals interactions), this part of MEA deforms easily when subjected to elevated pressure.

\section{Conclusions}

A three-layer MEA molecular model was established in this work comprising organic-inorganic composite material, namely Nafion oligomer, graphene, and Pt cluster. Thermal and moisture expansion properties of volume were investigated for each MEA layer. It is found that the CTE of the Nafion membrane decreases with increasing temperature and finally becomes flat, while for CLs, the CTE decreases in an initial period and then slightly increases
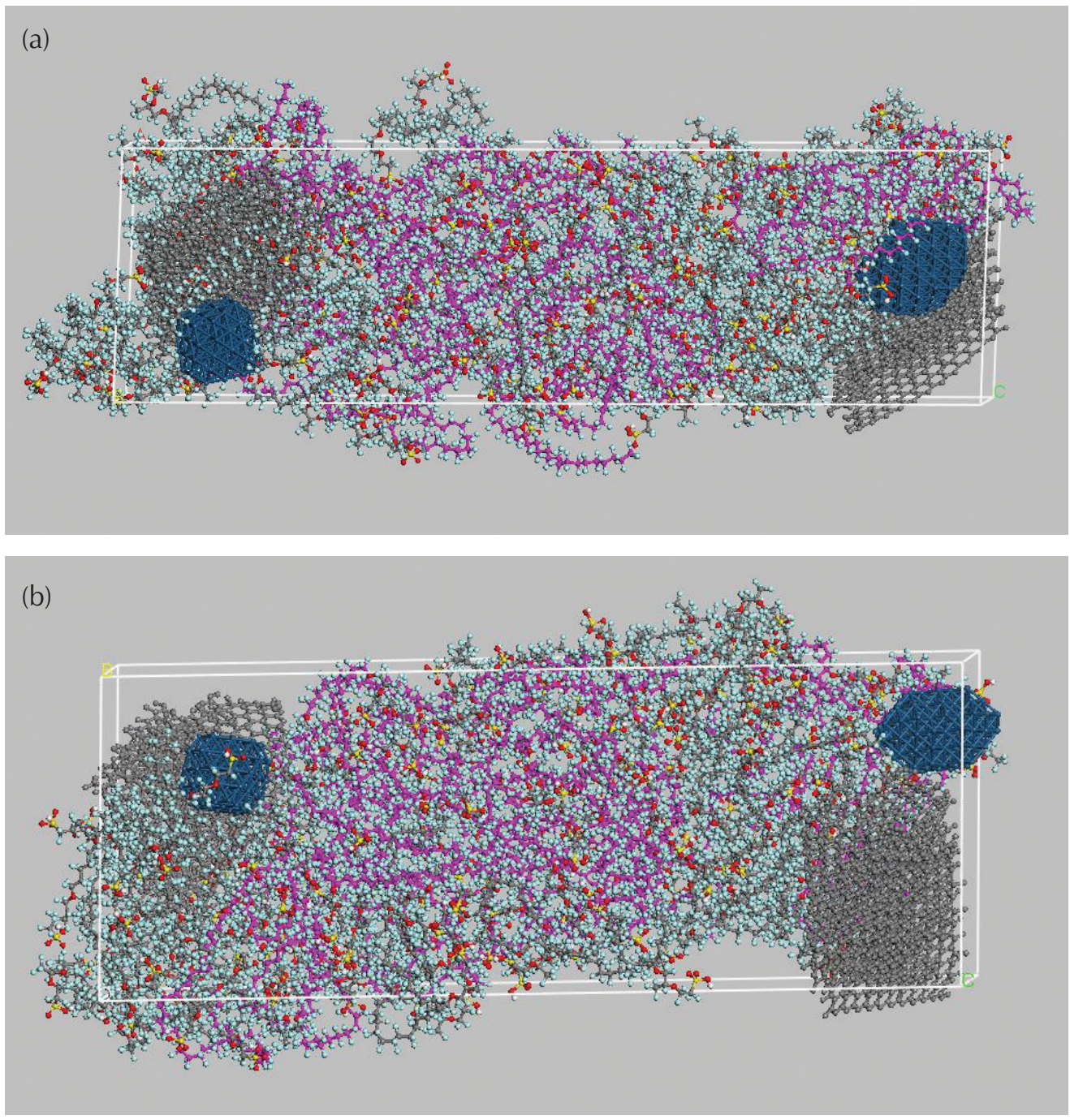

Fig. 5 - Equilibrium structure of MEA (a) under a pressure of $0.2 \mathrm{GPa}$; (b) under a pressure of $1 \mathrm{GPa}$ Slika 5 - Ravnotežna struktura MEA pri tlaku (a) 0,2 GPa i (b) 1 GPa 
with increasing temperature. In order to reduce the difference of CTE between CLs and membrane, two methods may be valid. One is to choose other high-efficiency catalysts that contribute a similar CTE-temperature curve with membrane; the other is to improve the working temperature range of $\mathrm{PEMFC}$, such as $45-80^{\circ} \mathrm{C}$. The CME for Nafion gradually increases, while for the $\mathrm{CL}$, it decreases with increasing moisture. The increase in Pt content makes $\mathrm{CME}$ become greater, thus, decreasing the Pt content can reduce the CME difference between MEA layers. Finally, we investigated the effect of pressure on the stability of the MEA structure. Our results show that, under a pressure of $0.2 \mathrm{GPa}$, the molecular structure of a MEA exhibits the lowest potential energy and a greater binding energy of $\mathrm{GN}$ and the Pt cluster; thus, it is a more stable structure.

This work may provide a model reference for designing MEA materials in real engineering.

\section{ACKNOWLEDGEMENTS}

The work was supported by the Specialized Research Fund for the Doctoral Program of Higher Education of China (Grant No. 20130072120068), the National Natural Science Foundation of China (Grant No. 11502170), and Research Funds for the Central Universities; it was also financially supported by the Key Laboratory for Advanced Civil Engineering Materials (Tongji University), Ministry of Education, China.

\section{List of abbreviations and symbols Popis kratica i simbola}

\footnotetext{
CCM - catalyst-coated membrane

- membrana presvučena katalizatorom

$\mathrm{CL}$ - catalyst layer

- katalitički sloj

CME - coefficient of moisture expansion

- koeficijent rastezanja pod utjecajem vlage

CTE - coefficient of thermal expansion

- koeficijent toplinskoga rastezanja

GN - graphene

- grafen

GN/Pt - graphene-supported platinum

- platina na grafenu

MEA - membrane electrode assembly

- membranski elektrodni sklop

MD - molecular dynamics

- molekulska dinamika

NPT - isothermal-isobaric ensemble

- izotermno-izobarni ansambl

PEMFC - polymer electrolyte membrane fuel cell - gorivne ćelije s polimernom membranom

PFSA - perfluorosulphonic acid

- perfluorsulfonska kiselina

UFF - universal force field

- univerzalno polje sila
}

$E_{\mathrm{B} / \mathrm{GN}-\mathrm{P} \mathrm{P} / \mathrm{A}}-$ binding energies between $\mathrm{GN}$ and Pt clusters in the anode layers, $\mathrm{kcal} \mathrm{mol}^{-1}$

- vezna energija između grafena i platinskih klastera u anodnom sloju, $\mathrm{kcal} \mathrm{mol}^{-1}$

$E_{\mathrm{B} / \mathrm{GN}-\mathrm{Pt} / \mathrm{C}^{-}}$binding energies between $\mathrm{GN}$ and Pt clusters in the cathode layers, $\mathrm{kcal} \mathrm{mol}^{-1}$

- vezna energija između grafena $\mathrm{i}$ platinskih klastera u katodnom sloju, $\mathrm{kcal} \mathrm{mol}^{-1}$

$E_{\mathrm{B} / \mathrm{M}-\mathrm{A}}$ - binding energies between the membrane and anode layer, $\mathrm{kcal} \mathrm{mol}^{-1}$

- vezna energija između membrane i anodnog sloja, $\mathrm{kcal} \mathrm{mol}^{-1}$

$E_{\mathrm{B} / \mathrm{M}-\mathrm{C}}$ - binding energies between the membrane and cathode layer, $\mathrm{kcal} \mathrm{mol}^{-1}$

- vezna energija između membrane i katodnog sloja, $\mathrm{kcal} \mathrm{mol}^{-1}$

$E_{\text {MEA }}$ - potential energy of the MEA structure, $\mathrm{kcal} \mathrm{mol}^{-1}$ - potencijalna energija MEA-strukture, $\mathrm{kcal} \mathrm{mol}^{-1}$

M - humidity (mass fraction of water in a system), \%

- vlažnost (maseni udjel vode u sustavu), \%

N $\quad$ - number of entities

- broj jedinki

p - pressure, GPa

- tlak, GPa

$T \quad$ - thermodynamic temperature, $\mathrm{K}$

- termodinamička temperatura, $\mathrm{K}$

V - volume

- obujam

$V_{0} \quad$ - volume at $298 \mathrm{~K}$

- obujam pri $298 \mathrm{~K}$

- mass fraction, $\%$

- maseni udjel, \%

$\alpha \quad-$ coefficient of moisture expansion in volume

- koeficijent rastezanja pod utjecajem vlage

$\gamma \quad$ - coefficient of volume thermal expansion

- obujmni koeficijent toplinskoga rastezanja

$\lambda \quad$ - hydration level, number of water molecules per sulfonate group

- hidratacija, broj molekula vode po sulfonskoj skupini

\section{References \\ Literatura}

1. B. C. H. Steele, A. Heinzel, Materials for fuel-cell technologies, Nature 414 (2001) 345-352, doi: http://dx.doi. org/10.1038/35104620.

2. X. Y. Huang, R. Solasi, Y. Zou, M. Feshler, K. Reifsnider, D. Condit, S. Burlatsky, T. Madden, Mechanical endurance of polymer electrolyte membrane and PEM fuel cell durability, J. Polym. Sci.: Part B: Polym. Phys. 44 (2006) 2346-2357, doi: http://dx.doi.org/10.1002/polb.20863.

3. D. Z. Wang, L. Wang, J. S. Liang, Z. X. Xia, S. L. Wang, Y. L. Zhu, C. Liu, G. Q. Sun, Formation of an integrated catalyst-coated membrane using electrohydrodynamic atomization Layer-by-Layer deposition for direct methanol fuel cells, J. Power Sources 224 (2013) 202-210, doi: http://dx.doi. org/10.1016/j.jpowsour.2012.09.092.

4. Y. Wang, K. S. Chen, J. Mishler, S. C: Cho, X. C. Adroher, A review of polymer electrolyte membrane fuel cells: Technology, applications, and needs on fundamental research, Appl. Energy 88 (2011) 981-1007, doi: http://dx.doi. org/10.1016/j.apenergy.2010.09.030. 
5. X. G. Yang, Y. Tabuchi, F. Kagami, C. Y: Wang, Durability of membrane electrode assemblies under polymer electrolyte fuel cell cold-start cycling, J. Electrochem. Soc. 155 (2008) B752-B761, doi: http://dx.doi.org/10.1149/1.2926505

6. Y. Tang, M. H. Santare, A. M. Karlsson, S. Cleghorn, W. B. Johnson, Stresses in proton exchange membranes due to hygro-thermal loading, J. Fuel Cell Sci. Technol. 3 (2006) 119-124, doi: http://dx.doi.org/10.1115/1.2173666.

7. A. Kusoglu, A. M. Karlsson, M. H. Santare, S. Cleghorn, W. $B$. Johnson, Mechanical response of fuel cell membranes subjected to a hygro-thermal cycle, J. Power Sources 161 (2006) 987-996, doi: http://dx.doi.org/10.1016/j.jpowsour.2006.05.020.

8. S. Kundu, M. W. Fowler, L. C. Simon, S. Grot, Morphological features (defects) in fuel cell membrane electrode assemblies, J. Power Sources 157 (2006) 650-656, doi: http:// dx.doi.org/10.1016/j.jpowsour.2005.12.027.

9. D. R. Xin, Q. Han, Estimating interfacial interaction energy of Cu-epoxy resin from molecular dynamics simulation, Electron. Mater. Lett. 10 (2014) 535-539, doi: http://dx.doi. org/10.1007/s13391-013-3197-9.

10. K. Li, N. Huo, X. P. Liu, J. Cheng, J. Y. Zhang, Effects of the furan ring in epoxy resin on the thermomechanical properties of highly crosslinked epoxy networks: a molecular simulation study, RSC Adv. 6 (2016) 769-777, doi: http://dx.doi. org/10.1039/C5RA22955C.

11. L. M. Yan, S. H. Zhu, X. B. Ji, W. C. Lu, Proton hopping in phosphoric acid solvated Nafion membrane: A molecular simulation study, J. Phys. Chem. B 111 (2007) 6357-6363, doi: http://dx.doi.org/10.1021/jp071005m.

12. J. W. Liu, N. Suraweera, D. J. Keffer, S. T. Cui, S. J. Paddison, On the relationship between polymer electrolyte structure and hydrated morphology of perfluorosulfonic acid membranes, J. Phys. Chem. C 114 (2010) 11279-11292, doi: http://dx.doi.org/10.1021/jp911972e.

13. S. Cui, J. Liu, M. E. Selvan, S. J. Paddison, D. J. Keffer, B. J. Edwards, Comparison of the hydration and diffusion of protons in perfluorosulfonic acid membranes with molecular dynamics simulations, J. Phys. Chem. B 112 (2008) 13273-13284, doi: http://dx.doi.org/10.1021/jp8039803.

14. S. H. Zhu, L. M. Yan, D. F. Zhang, Q. X. Feng, Molecular dynamics simulation of microscopic structure and hydrogen bond network of the pristine and phosphoric acid doped polybenzimidazole, Polymer 52 (2011) 881-892, doi: http:// dx.doi.org/10.1016/j.polymer.2010.12.037.

15. K. B. Daly, J. B. Benziger, P. G. Debenedetti, A. Z. Panagiotopoulos, Molecular dynamics simulations of water sorption in a perfluorosulfonic acid membrane, J. Phys. Chem. C 117 (2013) 12649-12660, doi: http://dx.doi.org/10.1021/ jp405440r.

16. Q. P. He, D. C: Joy, D. J. Keffer, Nanoparticle adhesion in proton exchange membrane fuel cell electrodes, J. Power Sources 241 (2013) 634-646, doi: http://dx.doi.org/10.1016/j. jpowsour.2013.05.011.

17. K. Malek, T. Mashio, M. Eikerling, Microstructure of catalyst layers in PEM fuel cells redefined: A computer approach, Electrocatalysis 2 (2011) 141-157, doi: http://dx.doi. org/10.1007/s12678-011-0047-0.

18. C. N. Sun, K. L. More, G. M. Veith, T. A. Zawodzinski, Composition dependence of the pore structure and water transport of composite catalyst layers for polymer electrolyte fuel cells, J. Electrochem. Soc. 160 (2013) F1000-F1005, doi: http://dx.doi.org/10.1149/2.055309jes.

19. Y. Q. Sun, Q. Wu, G. Q. Shi, Graphene based new energy materials, Energ. Environ. Sci. 4 (2011) 1113-1132, doi: http://dx.doi.org/10.1039/c0ee00683a.

20. B. Serger, P. V. Kamat, Electrocatalytically active Graphene-Platinum nanocomposites. Role of 2-D carbon support in PEM Fuel Cells, J. Phys. Chem. C 19 (2009) 79907995, doi: http://dx.doi.org/10.1021/jp900360k.

21. C. H. Cheng, K. Malek, P. C. Sui, N. Djilali, Effect of Pt nano-particle size on the microstructure of PEM fuel cell catalyst layers: Insight from molecular dynamics simulations, Electrochim. Acta 55 (2010) 1588-1597, doi: http://dx.doi. org/10.1016/j.electacta.2009.10.030.

22. S. Holdcroft, Fuel cell catalyst layers: A polymer science perspective, Chem. Mater. 26 (2014) 381-393, doi: http://dx. doi.org/10.1021/cm401445h.

23. S. L. Mayo, B. D. Olafson, W. A. Goddard III, Dreiding: A generic force field for molecular simulations, J. Phys. Chem. 94 (26) (1990) 8897-8909, doi: http://dx.doi.org/10.1021/ j100389a010.

24. R. Devanathan, N. Idupulapati, M. D. Baer, C. J. Mundy, M. Dupuis, Ab Initio molecular dynamics simulation of proton hopping in a model polymer membrane, J. Phys. Chem. 117 (2013) 16522-16529, doi: http://dx.doi.org/10.1021/ jp410229u.

25. C. H. Cheng, P. Y. Chen, C. W. Hong, Atomistic Analysis of Hydration and Thermal Effects on Proton Dynamics in the Nafion Membrane, J. Electrochem. Soc. 155 (4) (2008) B435-B442, doi: http://dx.doi.org/10.1149/1.2840631.

26. A. K. Rappé, C. J. Casewit, K. S. Colwell, W. A. Goddard, W. M. Skiff, UFF, A full periodic table force field for molecular mechanics and molecular dynamics simulations, J. Am. Chem. Soc. 114 (1992) 10024-10035, doi: http://dx.doi. org/10.1021/ja00051a040.

27. C. Feng, J. W. Wang, Y. M. Cheng, P. F. He, K. M. Liew, Diffusion mechanism of platinum nanoclusters on well-aligned carbon nanotubes, RSC Advances 4 (2014) 60711-60719, doi: http://dx.doi.org/10.1039/C4RA13185A.

28. Y. Ye, M. Tian, C. Zhang, Z. J. Du, J. G. Mi, Understanding Controls on Wetting at Fluorinated Polyhedral Oligomeric Silsesquioxane/Polymer Surfaces, Langmuir 32 (1) (2016) 230-238, doi: http://dx.doi.org/10.1021/acs.langmuir.5b02966.

29. J. M. Taylor, T. Komatsu, S. Dekura, K. Otsubo, M. Takata, H. Kitagawa, The Role of a Three Dimensionally Ordered Defect Sublattice on the Acidity of a Sulfonated Metal-Organic Framework, J. Am. Chem. Soc. 137 (35) (2015) 1149811506, doi: http://dx.doi.org/10.1021/jacs.5b07267.

30. Q. P. He, N. S. Suraweera, D. C. Joy, D. J. Keffer, Structure of the lonomer Film in Catalyst layers of Proton Exchange Membrane Fuel Cells, J. Phys. Chem. C 117 (48) (2013) 25305-25316, doi: http://dx.doi.org/10.1021/jp408653f. 


\section{SAŽETAK}

\section{Molekulski model i stabilnost strukture membranskog elektrodnog sklopa načinjenog od ionomera Nafiona

\author{
Cong Feng a Pengfei $\mathrm{He}^{\mathrm{b}^{*}}$
}

Jedan od najvažnijih dijelova gorivne ćelije s polimernom membranom (PEMFC) je membranski elektrodni sklop (MEA). Međutim, trajnost PEMFC-a uvelike se smanjuje odjeljivanjem membrane od elektrodnih slojeva potaknutog nejednakim naprezanjima zbog nekonzistentnog širenja pod utjecajem topline i vlage. $U$ ovome je radu prikazan molekulski model membrane i elektrodnih slojeva načinjen na temelju literaturnih podataka i s pomoću komercijalnog softvera radi pronalaženja stabilne strukture membranskog elektrodnog sklopa. Kao materijal membrane vodljive za protone razmatran je ionomer Nafion, a kao materijal elektroda kompozit Nafiona s platinom na grafenu. Ponašanje koeficijenta toplinskog rastezanja i koeficijenta rastezanja pod utjecajem vlage istraženo je molekulskom dinamikom. Strukturna stabilnost modela troslojnog sklopa MEA (anoda/membrana/katoda) proučena je uz djelovanje različitih vanjskih tlakova i računajući vezne energije između slojeva te između grafena i platine. Rezultati pokazuju da su pri vrlo visokim tlakovima molekule u unutrašnjosti previše zbijene pa se čestice platine odvajaju od nosača, dok s niskim tlakovima slabe veze između slojeva.

\section{Ključne riječi}

Molekulska dinamika, membranski elektrodni sklop, koeficijent toplinskog rastezanja, koeficijent rastezanja pod utjecajem vlage, vezna energija

${ }^{a}$ College of Materials Science and Engineering, Key Laboratory for Advanced Civil Engineering Materials (Ministry of Education), Tongji University, Shanghai 201804, Kina

${ }^{b}$ School of Aerospace Engineering and Applied Mechanics, Tongji University, Shanghai 200092, Kina
Izvorni znanstveni rad Prispjelo 22. travnja 2016. Prihvaćeno 25. srpnja 2016. 